\title{
Comparisons of the Root Mechanical Properties of three Native Mexican Tree Species for Soil Bioengineering Practices
}

\section{creative commons}

Botanical Sciences

95 (2): 259-269, 2017

DOI: $10.17129 /$ botsci.802

Copyright: (c) 2017 Sanchez-Castillo et al. This is an open access article distributed under the terms of the Creative Commons Attribution License, which permits unrestricted use, distribution, and reproduction in any medium, provided the original author and source are credited.

Author Contributions

Laura Sanchez-Castillo - conceived, designed, performed the experiments, wrote the paper. Tetsuya Kubota - conceived and designed the experiments. Israel Cantu-Silva - conceived and designed the experiments. Maria Yañez-Diaz - contribution in laboratory analysis. Hasnawir - contributed in data analysis and writing.

Miguel Pequeño-Ledezma - contributed in data analysis.

${ }^{1}$ Department of Forest and Biomaterial Science, Faculty of Agriculture, Kyoto University, Kyoto, Japan.

2 Faculty of Agriculture, Kyushu University, Fukuoka, Japan.

3 Faculty of Forestry Sciences, Autonomous University of

Nuevo Leon, Linares, Nuevo León, México.

${ }^{4}$ Environment and Forestry Research and Development Institute of Makassar, Ministry of Environment and Forestry of Indonesia, Makassar, South Sulawesi, Indonesia.

* Corresponding author email: laura@kyudai.jp

\section{Laura Sanchez-Castillo ${ }^{*}$, Tetsuya Kubota², Israel Cantu-Sillä, Maria Yañez-Diaz ${ }^{3}$, Hasnawir ${ }^{4}$, Miguel Pequeño-Ledezma ${ }^{3}$}

\section{Abstract}

Background: Urbanized slope areas in Sierra Madre Oriental are prone to sediment related disasters mainly caused by heavy rainfall episodes during hurricane season, knowledge on the factors on soil-roots dynamics are required to mitigate or lessen those disasters.

Questions and hypothesis: The mechanical properties of roots of native species vary according species. The mechanical properties of the roots are influenced by the morphology of root: diameter.

Species studied: Quercus rysophylla, Pinus pseudostrobus and Acacia berlandieri.

Study site and dates: Sierra Madre Oriental, Chipinque Ecological Park in Monterrey, Nuevo Leon. From middle of December 2014.

Methods: Selection of species was made base on widespread distribution and predominance in degraded areas. Samples were taken at field and tensile tests to calculate maximum force to root breakage were conducted using a laboratory dispositive, calculations of tensile strength and modulus of elasticity were calculated using formulas. The corresponding relations between root diameter and mechanical properties were established.

Results: Results confirmed that bigger diameters require bigger forces to break. In other hand, results confirmed the negative relationship between diameter and tensile strength and diameter and modulus of elasticity. Pointing out that roots of bigger diameter have less tensile strength and elasticity. The order of importance of the species studied according its mechanical properties was found like: Acacia berlandieri $>$ Quercus rysophylla $>$ Pinus pseudostrobus.

Conclusions: The results of this study begin the data contribution of the mechanical properties of native species of Sierra Madre Oriental in order to use it in the application of soil bioengineering practices on urbanized slopes prone to disasters.

Keywords: Root mechanical properties, native forest species, soil bioengineering, landslides, Sierra Madre Oriental.

\section{Comparaciones de las Propiedades Mecánicas de las Raíces de tres Especies Nati- vas Mexicanas para Practicas de Bioingeniería de Suelos}

\section{Resumen}

Antecedentes: Las pendientes urbanizadas en Sierra Madre Oriental son propensas a los desastres relacionados con sedimentos causados generalmente por lluvias intensas durante la temporada de huracanes, conocimiento en los factores de la dinámica suelo-raíces son indispensables para mitigar y aminorar esos desastres.

Preguntas e hipótesis: Las propiedades mecánicas de las raíces de especies nativas forestales varían de acuerdo a la especie. Las propiedades mecánicas de las raíces son influenciadas por la morfología de la raíz: diámetro.

Especies estudiadas: Quercus rysophylla, Pinus pseudostrobus y Acacia berlandieri.

Área de estudio y fechas: Sierra Madre Oriental, Parque Ecológico Chipinque, Monterrey, Nuevo León. Desde mediados de diciembre de 2014

Métodos: La selección de especies fue hecha en base a la distribución extensa y predominancia de las especies en áreas degradadas. Las muestras fueron tomadas en campo y las pruebas de tensión para calcular la fuerza máxima requerida para el quiebre de la raíz fueron conducidos usando un dispositivo en el laboratorio. La fuerza de tensión y módulo de elasticidad fueron calculados usando formulas. Las relaciones correspondientes entre el diámetro de la raíz y las propiedades mecánicas fueron establecidas.

Resultados: Los resultados obtenidos confirman que las raíces con diámetros mayores requieren de una fuerza mayor para romperse. Por otro lado, los resultados confirmaron la relación negativa entre el diámetro y la fuerza de tensión y el diámetro y el módulo de elasticidad. Esto señala que las raíces con diámetros mayores poseen menor fuerza de tensión y elasticidad. El orden de importancia de las especies estudiadas de acuerdo a sus propiedades mecánicas fue encontrado como: Acacia berlandieri $>$ Quercus rysophylla $>$ Pinus pseudostrobus.

Conclusiones: Los resultados de este estudio comienzan la contribución de datos de las propiedades mecánicas de las especies nativas de Sierra Madre Oriental para poder usarse en la aplicación de prácticas de Bioingeniería de suelos en laderas urbanas propensas a desastres.

Palabras clave: Propiedades mecánicas de la raíz, especies de bosque nativo, bioingeniería de suelo, deslizamientos de tierra, Sierra Madre Oriental. 
he role of roots of forest species in erosion control and slope stability is widely recognized and successfully used in soil bioengineering practices as an ecological alternative against sediment related disasters such as landslides (Stokes et al. 2014). Landslides are processes that result in movement of slope-forming materials such as rocks or soil with gravity and water as the primary triggers of landslides (Walker \& Shiels 2013).

Soil bioengineering is a unique approach of biotechnical stabilization in which plants themselves serve as the main structural and mechanical elements. In degraded areas, plants protect the slope providing stability so the surrounding vegetation can get a support and eventually colonize the entire slope (Gray \& Sotir 1996).

Mountainous regions like Sierra Madre Oriental in Mexico are prone to different types of sediment related disasters causing major economic and environmental problems. The risk of disasters due to the increasing urbanization and heavy rainfall caused by seasonal tropical storms and hurricanes in this area demands urgent counteracts against recurrent calamities (SanchezCastillo et al. 2015).

For the successful implementation of soil bioengineering practices to mitigate and lessen those disasters, knowledge on the factors involved on soil root reinforcement mechanisms are required. Roots are strong in tension and soils in the other hand are strong in compression and weak in tension, a combined effect of soil and roots results in a reinforced soil.

When shearing the soil, the roots mobilize their tensile strength whereby shear stresses that develop in the soil matrix are transferred to the roots fibers via tensile resistance of the roots (De Baets et al. 2008). However, soil-root system response to shearing depends on the roots failure mode. Roots can respond to shearing force in three different ways: stretching, slipping and breaking (Tosi 2007), thus, besides root tensile strength, the modulus of elasticity is also of interest because in many cases root tensile strength is not mobilized and the amount of mobilized tensile resistance will be a function of the modulus of elasticity or elongation-stretching capacity of roots (Hathaway \& Penny 1975, Gray \& Sotir 1996). Therefore, the assessing of both mechanical properties: tensile strength and modulus of elasticity is needed before the reinforcing effect of roots on soil can be accounted for in a reliable manner.

In this study, we quantify the root mechanical properties of Quercus rysophylla, Pinus pseudostrobus and Acacia berlandieri, three native species of Sierra Madre Oriental growing on disturbed slope areas for its further application in soil bioengineering practices for lessen the occurrence of sediment related disasters in urbanized slopes.

\section{Materials and Methods}

Study Area. The study was carried out in the slopes of Chipinque Ecological Park in Monterrey, Nuevo Leon, Mexico. Chipinque Ecological Park is located in Cumbres of Monterrey National Park in the northern portion of Sierra Madre Oriental. This park includes rugged terrain boasting steep mountains reaching elevations up to 2260 meters above sea level. This National Park was created in 1939 to protect the native flora and fauna against the spreading urbanization of Monterrey city the climate in the park changes drastically depending on the elevation and the location; Following Köppen classification the following climates are observed in the park. Elevation 600-1,000 m; North tip of the park has a (BWh) desert climate with an average annual temperature of $23{ }^{\circ} \mathrm{C}$ and an annual precipitation of $217 \mathrm{~mm}$. Elevation 1,000-2,000 m: North tip and the southwest corner of the park has a (BSk) Steppe Climate with an average annual temperature $21^{\circ} \mathrm{C}$. Elevation 2,000-3,000 m: Western side of the park has a (Cwb) Oceanic climate with an average annual temperature of $14{ }^{\circ} \mathrm{C}$ and an annual precipitation of $680 \mathrm{~mm}$. The general vegetation consists of Mixed Pine-Oak forest with species like: Pinus cembroides, $P$. hartwegii, $P$. pinceana, P. pseudostrobus, P. rudis, P. teocote. And Oaks like: Quercus fusiformis, Q. greggii, $Q$. hipoxlanta, $Q$. laeta, $Q$. rysophylla. And sub-montane shrubs in lower parts with species like: Acacia berlandieri, A. rigidula, Leucophyllum frutescens and Cordia boissieri.

Selection of species. Three native species of Sierra Madre Oriental slopes were selected for this study. From each of the three different elevations presented within the park, one species was selected based on their widespread distribution and predominance in degraded slope areas, 
such as: eroded slopes, shallow landslide disturbed slopes, cut-road slopes etc. The selection of native species for soil bioengineering proposes is crucial since vegetation should be compatible with soil and site conditions (temperature, light, soil type, water availability, nutrients, soil $\mathrm{pH})$. The selected native plants are presently growing on degraded sites or in surrounding areas which makes them the best candidates to consider because they already adapted to the site conditions and this may allow easy adaptation and growth for the application of soil bioengineering techniques in disturbed slope areas. Once it has been determined if the species are suitable in the area, the above and below-ground morphological characteristics such as: stem density, potential to trap sediment and organic debris, root density, root area, root system morphology were considered as a key physical selection criteria. Similar selection system was proposed by Reubens et al. (2011) and widely used in other studies (De Baets et al. 2009, Stokes et al. 2009, Giadrossich et al. 2013, Vergani et al. 2014, Ghestem et al. 2014, Stokes et al. 2014).

The species included in this study are:

Quercus rysophylla Weath.- an evergreen tree of rapid growth, which can reach $25 \mathrm{~m}$ of height. The leaves are alternate, simple, rigid and elliptic from 7 to $25 \mathrm{~cm}$ long and between 2 to $8 \mathrm{~cm}$ wide. When the leaves become mature they become smooth, shiny and of dark green color on the top. Acorns are ovoid, mucronate, and glabrous at maturity, its length is from 1 to $1.7 \mathrm{~cm}$, single or in pairs, sessile. The cupola, golden colored silky when young, occupies one-third and mature after 2 years (Nixon 1998). This specie is endemic to Mexico and found mostly at mid altitudes in the Sierra Madre Oriental.

Pinus pseudostrobus Lindl.- It's an evergreen native tree species of Mexico from the temperate forest between 1,300 to $3,250 \mathrm{~m}$ from 26 to $15^{\circ} \mathrm{N}$. Usually 3 to 45 meters high, the trunk is straight and with a diameter of 40 to $80 \mathrm{~cm}$, this species is free of branches at $50 \%$ of its height. It is widely distributed and in many places common or abundant pine of montane to high montane habitat in cold temperate to warm temperate zones, it is an important constituent of mixed conifer pine and pine-oak forests. In disturbed forests it may survive as scattered groves or as individual trees (Farjon 2013).

Acacia berlandieri Benth.- is a spreading shrub native in northeast Mexico and southwestern United States that belongs to the subfamily Mimosoideae of Fabaceae. It grows from 1 to 5 meters tall with blossoms that are spherical and white, the blooming season is from February through April. The white-to-cream-colored flowers (yellowing with age), grow in ball-like clusters, 5/8 inch or more in diameter, and are quite fragrant. They have 50 to 100 or more stamens, but no petals. The pinnately compound leaves are delicate, almost fernlike, 13 to $20 \mathrm{~cm}$ long with 12 to $22 \mathrm{~cm}$ (sometimes up to $45 \mathrm{~cm}$ ) pairs of leaflets, and these leaflets are again divided into 30 to 50 leaflets (Hatch et al. 1990). It is usually found on the hillsides and slopes of northeast Mexico.

Sampling. Complying the government's regulations on natural protected areas, samples were collected from individuals with root system exposed, to avoid serious disturbance in the study area. 5 to 7 individuals on degraded slope areas were selected, the variation in the number of individuals was according the situation encountered, for example: root exposure, location on slope, size and root decay situation. 3 to 5 root samples per individual with lengths ranging from 30 to $70 \mathrm{~cm}$ were cut from the area within a 1 meter ratio from the trunk. Samples were carefully packed to keep them fresh during transportation to the Laboratory of Forest Conservation and Soil Nutrition of the Autonomous University of Nuevo Leon.

In the laboratory damaged roots were discarded and samples were cut with sharp scissors and labeled for further analysis the size of the samples for testing was decided based on the testing machine capacity: maximum length of $10 \mathrm{~cm}$ and maximum diameter of $10 \mathrm{~mm}$. After cutting, all samples were kept inside a desiccator to preserve the original moisture of roots and immediately subjected to tensile tests.

Tensile tests. Tensile tests were conducted using the Universal Testing Machine SHIMADZU SLFL-100 KN manufactured in Japan. Root samples were carefully positioned and clamped to the experimental device in both extremities avoiding any damage. Diameters were measured at 
three different points with a digital caliper Mitutoyo the three diameters were used to calculate a mean diameter to assure a representative value corresponding to the breaking point of the samples, hence, diameters were not measured at the ends of the sample. The machine pulled each sample at a constant speed of $10 \mathrm{~mm} / \mathrm{min}$.

Tests were considered invalid when the sample slipped from the clamps or broke in the clamping points because this kind of rupture could have been caused by root system damage and did not reflect mechanical properties under tension. Example of valid breakage is shown in Figure 1.

Data and laboratory analysis. Maximum force to root breakage $\left(\mathrm{F}_{\max }\right)$ that represents the peak value in were roots break by tension was measured directly from the Universal Testing Machine. Tensile strength force $\left(\mathrm{T}_{\mathrm{s}}\right)$ that is the capacity of root samples to withstand tension (being pulled apart) and the modulus of elasticity $\left(\mathrm{E}_{\text {root }}\right)$ represents the resistance of samples to be deformed

Figure1. Example of a valid root breakage during tension tests.

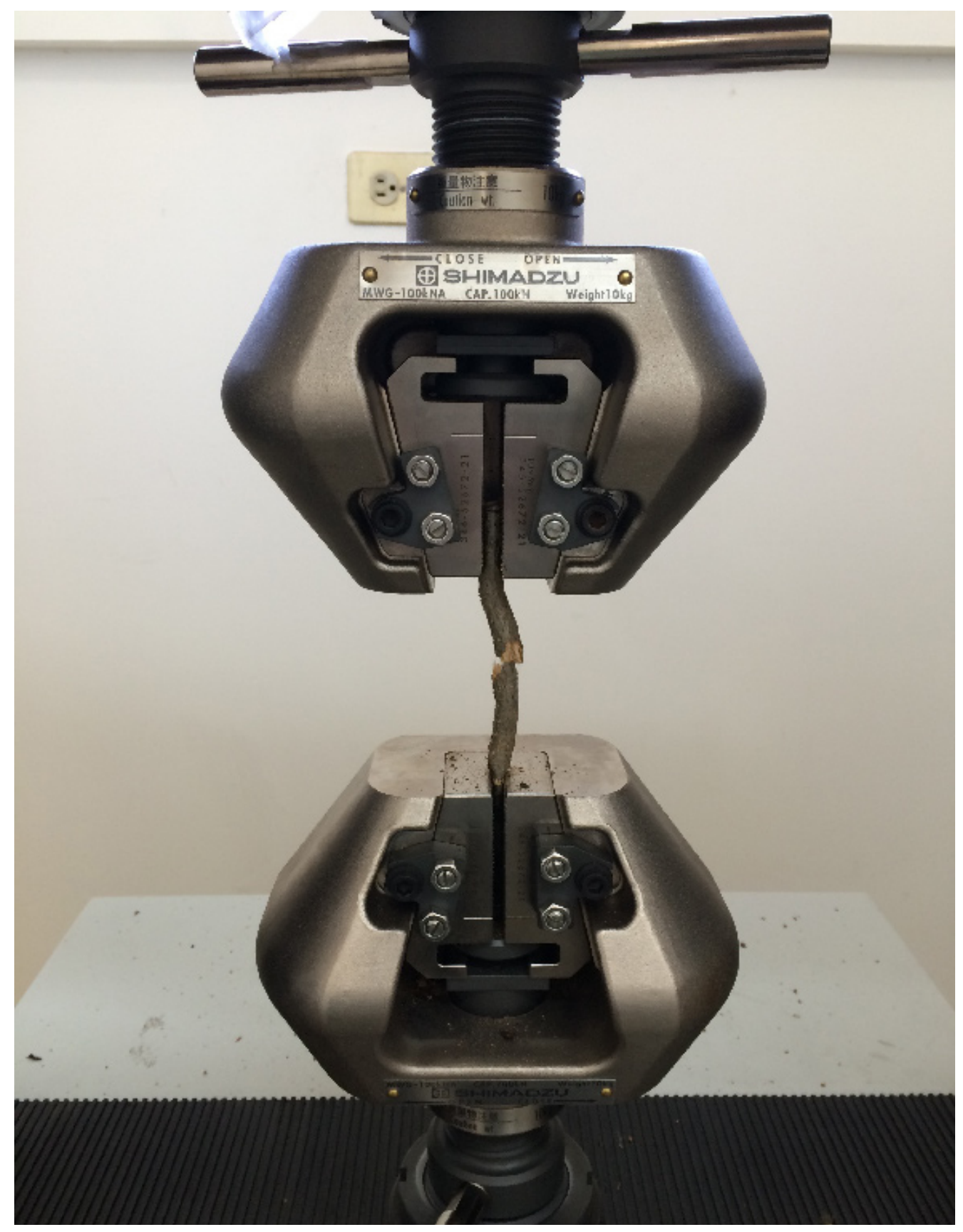


elastically were obtained inputting the following formulas in the software TRAPEZIUM X. Tensile strength values were obtained using the following formula:

$$
T_{s}=F_{\max } / \pi(D / 2)^{2}
$$

where $\mathrm{F}_{\max }$ is the maximum force to root breakage $(\mathrm{N})$ and $\mathrm{D}$ is the average root diameter $(\mathrm{mm})$ (Mattia et al. 2005, Genet et al. 2005, Bischetti et al. 2005, De Baets et al. 2008).

Elastic properties of each root sample were determined using the modulus of elasticity $\left(\mathrm{E}_{\text {root }}\right)$ as:

$$
E_{\text {root }}=\frac{F_{\max } / A_{0}}{\mathrm{C} E / L_{0}}
$$

where $\mathrm{F}_{\text {max }}$ is the maximum force applied to the object under tension, $A_{0}$ is the original cross sectional area, $\mathrm{C} E$ is the change of length of the sample and $L_{0}$ is the original length (Ammann et al.2009).

Moisture content of samples was calculated with the following formula:

$$
\text { Moisture content }=\frac{\text { original weight } E \text { dryweight }}{d r y \text { weight }} \times 100
$$

Samples weight was obtained using a Balance Pioneer and oven-dried at $115^{\circ} \mathrm{C}$ for 48 hours.

Statistical analysis was carried out with SPSS Statistics Version 22, following the assumptions of normal distribution and equality of variances using the one-way ANOVA. Regression curve estimation was performed to explore the function between diameter and the mechanical properties of roots. Data was graphically screened to determine to which model variables are related according coefficient of determination. Pearson correlation coefficient was computed to assess the relationship between diameter and mechanical properties of roots.

\section{Results}

The number of samples successfully tested included 54 of Quercus rysophylla, 37 of Pinus pseudostrobus and 27 of Acacia berlandieri. Tension tests were conducted successfully on $68 \%$ of the total collected samples. The remaining $32 \%$ failed by root system damage instead of the applied tension. Details of the mechanical properties obtained can be observed in Table 1.

Table 1. Maximum, minimum and average values Maximum force to root breakage $\left(\mathrm{F}_{\max }\right)$, Tensile strength $\left(\mathrm{T}_{\mathrm{s}}\right)$ and Modulus of elasticity $\left(\mathrm{E}_{\mathrm{root}}\right)$ of the species studied.

\begin{tabular}{lcccccccccc} 
& \multicolumn{3}{c}{$\boldsymbol{F}_{\max }(\mathbf{N})$} & \multicolumn{3}{c}{$\boldsymbol{T}_{\mathbf{s}}\left(\mathbf{N} / \mathbf{m m}^{2}\right)$} & \multicolumn{3}{c}{$\boldsymbol{E}_{\text {root }}\left(\mathbf{N} / \mathbf{m m}^{2}\right)$} \\
\hline Species & Max & Min & Ave & Max & Min & Ave & Max & Min & Ave \\
Q. rysophylla & 606.25 & 18.75 & 178.70 & 22.80 & 1.43 & 8.31 & 504.01 & 30.43 & 161.80 \\
P. pseudostrobus & 671.87 & 31.25 & 205.48 & 21.50 & 1.54 & 7.52 & 177.19 & 18.63 & 71.30 \\
A. berlandieri & 706.25 & 21.87 & 276.73 & 22.81 & 4.24 & 11.86 & 680.28 & 39.11 & 184.07 \\
\hline
\end{tabular}
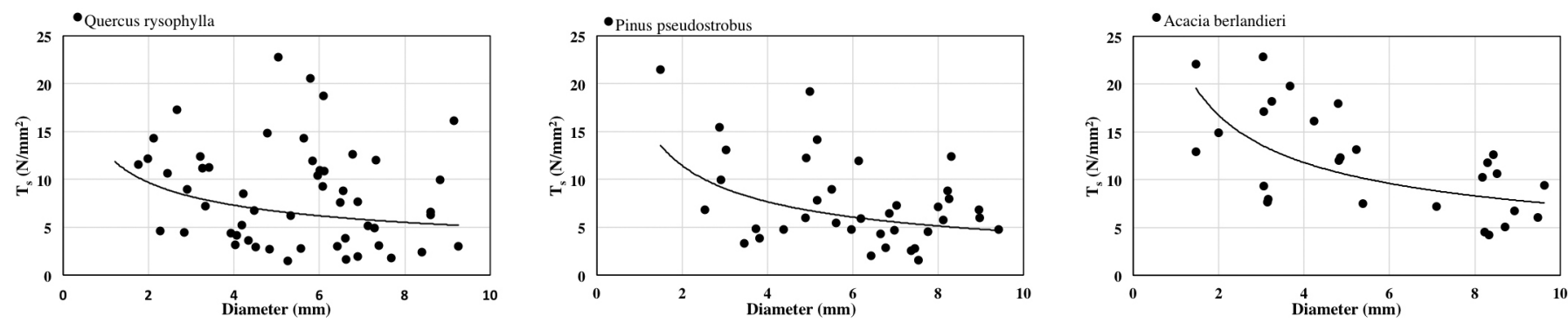

Figure 2. Variation of tensile strength $\left(\mathrm{T}_{\mathrm{s}}\right)$ and diameter of the species analyzed. 

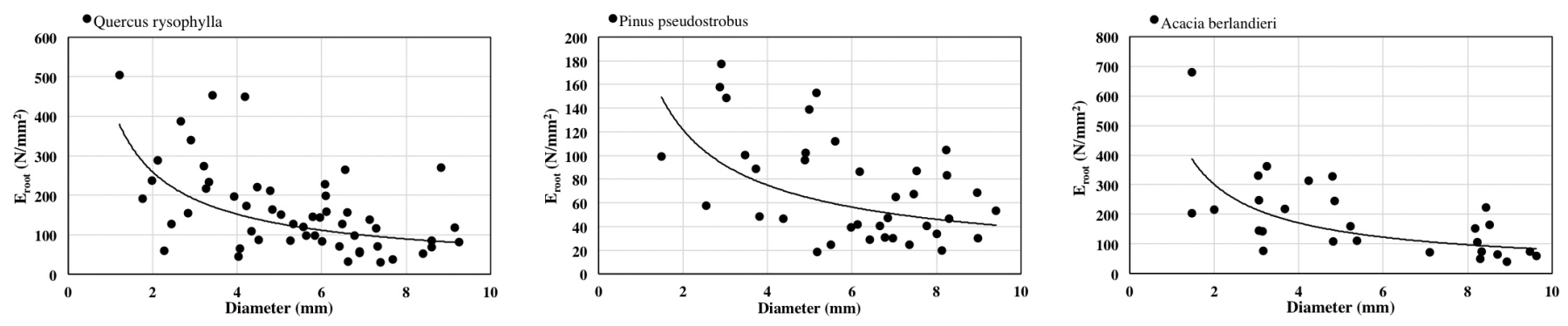

Figure 3. Variation of modulus of elasticity $\left(\mathrm{E}_{\text {root }}\right)$ and diameter of species analyzed.
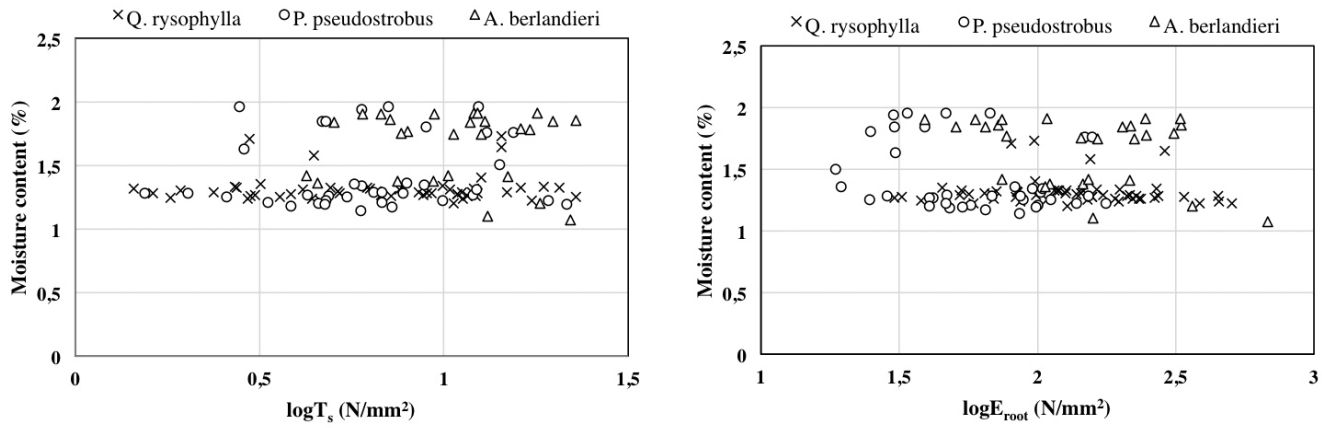

Figure 4. Relationship between moisture content of roots $(\%)$, tensile strength $\left(\mathrm{T}_{\mathrm{s}}\right)$ and modulus of elasticity $\left(\mathrm{E}_{\text {root }}\right)$.

The relationship between root diameter and $\mathrm{T}_{\mathrm{s}}$ is shown in Figure 2. The relationship is negative and could be fitted with a power law equation Quercus rysophylla $\left(\mathrm{y}=12.81 \mathrm{x}^{1.306}\right.$ $\left.R^{2}=0.0586\right)$, Pinus pseudostrobus $\left(\mathrm{y}=17.079 \mathrm{x}^{-0.579} R^{2}=0.1594\right)$ and Acacia berlandieri $(\mathrm{y}=$ $\left.23.745 \mathrm{x}^{-0.505} R^{2}=0.3654\right)$. The ranking of species by average $\mathrm{T}_{\mathrm{s}}$ is: Acacia berlandieri $>$ Quercus rysophylla $>$ Pinus pseudostrobus. Correlation results were significant as: diameter and $\mathrm{T}_{\mathrm{s}}(R=$ $-0.29 p<0.05)$.

The relationship between diameter of roots and $\mathrm{E}_{\text {root }}$ was also negative for all species tested (Figure 3). Power law equation fitted the results as: Quercus rysophylla $\left(\mathrm{y}=440.06 \mathrm{x}^{-0.768} R^{2}=\right.$ $0.2749)$, Pinus pseudostrobus $\left(\mathrm{y}=197.48 \mathrm{x}^{-0.7} R^{2}=0.2201\right)$ and Acacia berlandieri $\left(\mathrm{y}=529.6 \mathrm{x}^{-0.816}\right.$ $\left.R^{2}=0.4456\right)$. The order of species by average $\mathrm{E}_{\text {root }}$ as: Acacia berlandieri $>$ Quercus rysophylla $>$ Pinus pseudostrobus. Correlation results were significant as: diameter and $\mathrm{E}_{\mathrm{root}}(R=-0.47$ $p<0.05)$.

The average moisture content percentage of root samples by species was: Quercus rysophylla $21.5 \%$, Pinus pseudostrobus $32.8 \%$ and Acacia berlandieri $55.1 \%$. There is not clear relationship between moisture content of roots $(\%)$, tensile strength $\left(\mathrm{T}_{\mathrm{s}}\right)$ and modulus of elasticity $\left.\mathrm{E}_{\text {root }}\right)$.

\section{Discussion}

Wide variations of tensile strength and modulus of elasticity of roots of forest species have been reported by previous authors (O’Loughling \& Watson 1979, Greenway 1987, Watson et al. 1999, Abernethy \& Rutherfurd 2001, Genet et al. 2005, Mickovski et al. 2007, Tosi 2007, Fan \& Su 2008, Ali 2010, Comino \& Marengo 2010, Schwarz et al. 2010). It is important to recognize that the mechanical properties are affected not only by species and diameter differences but other factors might be involved as well. As reported by Gray \& Sotir (1996) the tensile strength values of hardwood species vary approximately from 8 to $80 \mathrm{~N} / \mathrm{mm}^{2}$ with diameters from 2 to 
Table 2. Comparison of Tensile strength $\left(\mathrm{T}_{\mathrm{s}}\right)$ and Modulus of elasticity $\left(\mathrm{E}_{\mathrm{rot}}\right)$ values with different studies and species.

\begin{tabular}{|c|c|c|c|}
\hline Type & Spp & $\mathbf{T}_{\mathrm{s}}(\mathbf{N})$ & $E_{\text {root }}(N)$ \\
\hline \multirow[t]{10}{*}{ Shrubs } & Acacia berlandieri* & 11 & 184.07 \\
\hline & Spartium junceum & 29.93 & 779.67 \\
\hline & Rosa canina & 22.95 & 542.7 \\
\hline & Inula viscosa & 18.72 & 512.05 \\
\hline & Cotoneaster dammeri & 42.9 & \\
\hline & Uniperus horizontalis & 14.8 & \\
\hline & Atriplex halimus & 57.2 & \\
\hline & Pistacia lentiscus & 55 & \\
\hline & Kunzea ericoides & 32.45 & \\
\hline & Melastoma malabathricum & 29.72 & \\
\hline \multirow[t]{16}{*}{ Trees } & Quercus rysophylla* & 8.31 & 161 \\
\hline & Pinus pseudostrobus* & 7.52 & 71.3 \\
\hline & Alnus incana & 32 & \\
\hline & Pinus densiflora & 32 & \\
\hline & Picea abies & 27 & \\
\hline & Quercus robur & 32 & \\
\hline & Salix fragilis & 18 & \\
\hline & Salix hastata & 13 & \\
\hline & Salix cinerea & 11 & \\
\hline & Pinus radiata & 18 & \\
\hline & Melaleuca ericifolia & 35 & \\
\hline & Eucalyptus camaldulensis & 22.8 & \\
\hline & Pinus radiata & 17.6 & \\
\hline & Populus yunnamensis & 38.4 & 121 \\
\hline & Populus deltoides & 36.3 & 363 \\
\hline & Salix matsundana & 36.4 & 108 \\
\hline
\end{tabular}

$15 \mathrm{~mm}$, the species analyzed in this study ranged from 8.31 to $11.86 \mathrm{~N} / \mathrm{mm}^{2}$ with diameters from 1.21 to $9.41 \mathrm{~mm}$ and $\mathrm{E}_{\text {root }}$ values ranged from 71.30 to $184.07 \mathrm{~N} / \mathrm{mm}^{2}$.

Tensile strength $\left(\mathrm{T}_{\mathrm{s}}\right)$ and Modulus of elasticity $\left(\mathrm{E}_{\mathrm{roo}}\right)$ values obtained in this study were compared with data from different studies and species, comparison is shown in Table 2. Acacia berlendieri average tensile strength $(11.86 \mathrm{~N})$ is smaller but closer to Juniperus horizontalis (14.8 $\mathrm{N}$ ) and is distant from the average tensile strength of shrubs tested in previous studies. However, if we compare the maximum tensile strength of Acacia berlandieri $(22.81 \mathrm{~N})$ with the average values of other shrubs, the results are closer, e.g. Inula viscosa $(18.72 \mathrm{~N})$, Rosa canina $(22.95$ N), Melastoma malabathricum (29.72 N), Spartium junceum (29.93 N). In the case of trees, tensile strength average values, Quercus rysophylla $(8.31 \mathrm{~N})$ and Pinus pseudostrobus $(7.52$ $\mathrm{N})$ are close to Salix cinerea $(11 \mathrm{~N})$ and Salix hastata $(13 \mathrm{~N})$, however, when maximum tensile strength of Quercus rysophylla $(22.80 \mathrm{~N})$ and Pinus pseudostrobus $(21.50 \mathrm{~N})$ is compared the closeness with other species tested is higher e.g. Salix fagilis $(18 \mathrm{~N})$, Pinus radiate (18 N), Picea abies $(27 \mathrm{~N})$. Modulus of elasticity $\left(\mathrm{E}_{\text {root }}\right)$ data in trees is scarce to make a proper comparison and is limited to three tree species of poplar and willow tested without bark by Hathaway \& Penny (1975), however average values are close to the ones presented in this study. However, in the case of Acacia berlandieri, $\mathrm{E}_{\text {root }}$ maximum values fit better the values presented by shrubs in other studies.

From these comparisons of the differences encountered on $\mathrm{T}_{\mathrm{s}}$ and $\mathrm{E}_{\text {root }}$ values in respect of values reported by previous studies, we can infer that the values obtained in this study could be influenced by the combination of species-specific differences, specimens and site specific conditions. These influences can also be observed on $\mathrm{T}_{\mathrm{s}}$ and Dm relationships, that although show a trend, a relatively poor fitting of models for Quercus rysophylla and Pinus Pseudostrobus can 
Figure 5. Idealized root system.

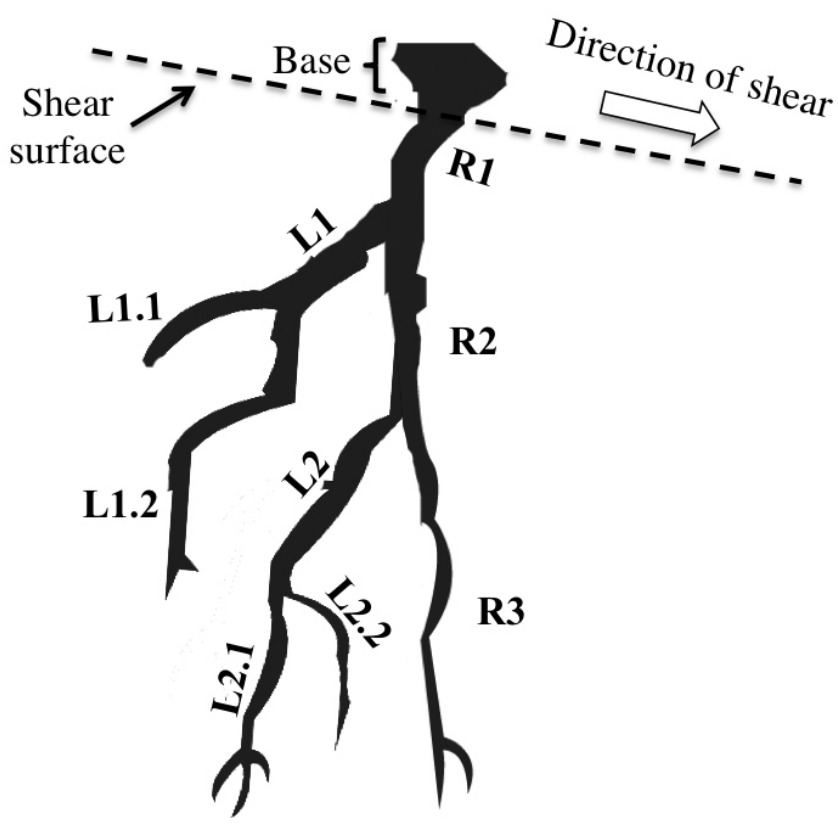

be observed, this is expected given the numerous factors different from diameter controlling $\mathrm{T}_{\mathrm{s}}$. Similar low fitting results were found on previous studies and were suggested as: Variations in root age (Genet et al. 2005), growth rate, nutrient status (Pollen \& Simon 2005), climate and time of sampling (Operstein \& Frydman 2000). Root moisture content was not an influential factor for $\mathrm{T}_{\mathrm{s}}$ according the results obtained in this study similarly to the results presented by Pollen (2007) and Tosi (2007), however, Gray \& Barker (2004) found differences of $\mathrm{T}_{\mathrm{s}}$ between moisture and air dried roots. Therefore, as explained, differences between values and the relatively poor fitting of models are probably the product of the combination or separate action of different factors like: species specific differences. growth environment, age of specimens, differences of specimens-related conditions and site differences. It should be noted that samples tested in this study were taken from different specimens without discrimination of age, root system position or any affectation of external stresses like wind or road cutting, etc., owing to the enormous challenge or impossibility of homogenize individuals on field conditions. However, these research limitations open the doors to further laboratory works under controlled conditions on this matter.

The results obtained in this study corroborate the premise that several authors have reported: a clear decrease in root tensile strength with increasing diameter size (Operstein \& Frydman 2000, Tosi 2007, Fan \& Su 2008, Hales et al. 2009, Schwarz et al. 2010). This negative relationship is explained by Genet et al.(2005) as differences in root structure attributing it to the high cellulose content in thinner roots, they reached this conclusion based on their results showing that tensile strength increased with the decreasing root diameter and increasing cellulose content of the species studied. The modulus of elasticity $\left(\mathrm{E}_{\text {root }}\right)$ of the species studied decreased with increasing root diameter showing the same pattern as tensile strength $\left(\mathrm{T}_{\mathrm{s}}\right)$ These two variables are significantly associated according Pearson's correlation coefficient $(R=0.481 p<0.05)$.

It is necessary to distinguish between root tensile strength of a root system itself and the tensile strength of a root segment. Tree species usually develop two kind of roots: long and short roots the long type of roots usually become part of the root system for anchorage and short type roots emerge as lateral branches that do not undergo secondary thickening and are thinner compared long roots (Hermann 1977), due to the testing machine diameter limitations the root segments tested belong to the part of root system a meter away from the trunk, in a horizontal plane with diameters ranging from 1 to $10 \mathrm{~mm}$ corresponding to lateral roots segments. In an idealized root system, if tensile force at base root is applied, failure may occur anywhere in the first root seg- 
ment (R1), also because load distribution between lateral branch (L1) and second segment of root (R2), failure may occur first in the lateral (L1) and then in the second segment of root (R2), at which point the root system fails (Figure 5). Tensile strength values presented in this study gives a reasonable prediction of strengths needed at first instances of root failure (Wu \& Watson 1998, Morgan \& Rickson 1995), which allows the comparison between species and quantification of potential use against sediment related disasters.

However, a distinction should be made in the results of Pinus pseudostrobus, whose root bark is ticker, brittle and of cracked texture compared to other species. This kind of root barks may hide some defects such as: flaws, cracks, decay parts and are generally hard to notice because its rough texture, which can indeed affect the results obtained. The samples of Pinus pseudostrobus were tested with bark because the intention of this study is to get reliable values of root mechanical properties encountered on field, for this reason all the root samples were tested the closest possible to on-field natural conditions and no alterations were made to samples after collection. It is known that when sediment disasters occur, the root bark contributes to the resistance of roots by increasing root-soil friction through bark roughness, this can be observed on field pull out tests (Karrenberg et al. 2003). However, when load bearing capacity of the root tissue is tested, root bark could become a prejudicial factor on the acquisition of reliable data. Therefore, diameter is not a reliable indicator for species having root barks with considerable thickness (De Baets et al. 2008), this should be considered in further studies intended to use tensile strength values for the mitigation of sediment related disasters. The sample's length doesn't play any prejudicial factor on tensile strength as all samples tested were the same size, however, previous studies have indicated that the differences between thinner roots and thicker roots tensile strength decreases when longer roots are tested and might be influenced by defects on the root material, this behavior is similar to some fibers (Sirichaisit \& Young 1999, Lim et al. 2010, Chen et al.2012).

Generally, during a slope failure, the roots can slip, break or stretch. Slipping of roots is influenced by soil characteristics, but when breaking roots are present the tensile strength is the most important parameter to consider, however, when stretching of roots occur, the modulus of elasticity is an important characteristic to analyze.

The mechanical properties of the root systems of the native forest species analyzed were clarified for its application in soil bioengineering practices, however, further analyses of root system morphological characteristics such as depth, volume and root system distribution should be done. It is important to recognize that in case of landslides the effectiveness of the mechanical stabilization by roots depends mainly on the specific slope conditions and to relate those characteristics to the individual properties of each forest species considered.

\section{Conclusions}

The urbanized slopes of Sierra Madre Oriental are affected by sediment related disasters every year especially during hurricane season, which discloses the urgent need of soil bioengineering practices to mitigate and prevent sediment related disasters in populated areas.

Successful application of soil bioengineering practices for soil stabilization in sediment related disaster prone areas requires knowledge on the factors governing the mass and surficial stability of affected slopes. If plants are to serve as soil reinforcements (main structural and mechanical elements) the assessment of roots mechanical properties growing in the area of interest is required to make an optimal choice of species, looking towards the establishment of a slope protection system.

In this regard, the root mechanical properties of three different native species growing in disturbed soil were tested. The relationship between diameter of roots and tensile strength $\left(\mathrm{T}_{\mathrm{s}}\right)$ and diameter and modulus of elasticity $\left(\mathrm{E}_{\text {root }}\right)$ was found negative, indicating that roots with smaller diameters have bigger tensile strengths and elasticity. It was also confirmed that the power law 
equation is able to model the relation between the mechanical properties and diameter of the roots of the different species analyzed.

The order of species according its mechanical properties was established as: Acacia berlandieri $>$ Quercus rysopylla $>$ Pinus pseudostrobus. The $\left(\mathrm{E}_{\text {root }}\right)$ average value of Acacia berlandieri was bigger compared to Quercus rysophylla, however as discussed, Pinus pseudostrobus root bark might be and influential factor on the results obtained. The results of this study demonstrated that the mechanical properties of shrub species (Acacia berlandieri) can be equal and even surpass the mechanical properties of tree species (Quercus rysophylla and Pinus pseudostrobus). Thereby, implementation of soil bioengineering practices using Acacia berlandieri for the lower elevation zones and Quercus rysophylla for the high elevation parts would be the best options of species selection for the improvement of efficiency of rehabilitation actions in urbanized slopes of Sierra Madre Oriental.

The data obtained begin the contribution of the mechanical characteristics of root systems of native species of the forest of Sierra Madre Oriental as the present lack of knowledge on this area has been a limiting factor for the implementation of soil bioengineering practices.

\section{Literature cited}

Abernethy B, Rutherfurd ID. 2001. The distribution and strength of riparian tree roots in relation to riverbank reinforcement. Hydrological Processes 15:63-79.DOI:10.1002/hyp.152

Ali F. 2010. Use of vegetation for slope protection: Root mechanical properties of some tropical plants. International Journal of Physical Sciences 5:496-506.

Ammann M, Böll A, Rickli C, Speck T, Holdenrieder O. 2009. Significance of tree root decomposition for shallow landslides. Forest Snow and Landscape Research 82:79-94.

Bischetti GB, Chiaradia EA, Simonato T. Speziali B, Vitali B, Vullo P, Zocco A. 2005. Root strength and root area ratio of forest species in Lombardy (Northern Italy). Plant and Soil 278:11-22. DOI: 10.1007/ s11104-005-0605-4

Comino E, Marengo P. 2010. Root tensile strength of three shrub species: Rosa canina, Cotoneaster dammeri and Juniperus horizontalis: Soil reinforcement estimation by laboratory tests. Catena 82:227-235. DOI:10.1016/j.catena.2010.06.010

Chen L, Jiang J, Zhou S. 2012. Effects of gauge length and strain rate on the tensile strength of tree roots. Trees 26:1577-1584.

De Baets S, Poesen J, Reubens B, Wemans K, De Baerdemeaker J, Muys B. 2008. Root tensile strength and root distribution of typical Mediterranean plant species and their contribution to soil shear strength. Plant Soil 305:207-226. DOI: 10.1007/s11104-008-9553-0

De Baets S, Poesen J, Reubens B, Muys B, De Baerdemaeker J, Meersmands J. 2009. Methodological framework to select plant species for controlling rill and gully erosion: application to a Mediterranean ecosystem. Earth Surface Processes and Landforms 34:1374-1392. DOI: 10.1002/esp.1826

Fan C-C, Su C-F. 2008. Role of roots in the shear strength of root-reinforced soils with high moisture content. Ecological Engineering 33:157-166. DOI: 10.1016/j.ecoleng.2008.02.013

Farjon A. 2013. Pinus pseudostrobus. The IUCN Red List of Threatened Species. Version 2014.2. Available: <www.iucnredlist.org> (Accessed on 04/2015)

Genet M, Stokes A, Salin F, Mickovski SB, Fourcaud T, Dumail JF, Van Beck R. 2005. The influence of cellulose content on tensile strength in tree roots. Plant and Soil 278:1-9. DOI: 10.1007/s11104-0058768-6

Ghestem M, Veylon G, Bernard A, Vanel Q, Stokes A. 2014. Influence of plant roots system morphology and architectural traits on soil shear resistance. Plant and Soil 377:43-61. DOI: 10.1007/s11104-0121572-1

Giadrossich F, Schwarz M, Cohen D, Preti F, Or D. 2013. Mechanical interactions between neighboring roots during pullout tests. Plant Soil 367:391-406. DOI: 10.1007/s11104-012-1475-1

Gray DH, Barker D. 2004. Root-soil mechanics and interactions. In: Bennett JJ, Simon A,eds. Riparian vegetation and fluvial geomorphology. New York: Water Science and Application 8. American Geophysical Union, 113-123.

Gray DH, Sotir RB. 1996. Biotechnical and Soil Bioengineering Slope Stabilization: A practical Guide for Erosion Control. New York: John Wiley \& Sons.

Greenway DR. 1987. Vegetation and slope stability. In: Anderson, M.G., Richards, K.S, eds. Slope Stability-geotechnical engineering and geomorphology. Chichester:John Wiley \& Sons, 187-230. 
Received:

May 16th, 2016

Accepted:

December 5th, 2016
Hales TC, Ford CR, Hwang T, Vose JM, Band LE. 2009. Topographic and ecologic controls on root reinforcement. Journal of Geophysical Research 114:F03013. DOI:10.1029/2008JF001168

Hathaway RL, Penny D. 1975. Root strength in some Populus and Salix clones. New Zeland Journal of Botany 13:333-344. DOI: 10.1080/0028825X.1975.10430330

Hatch SL, Gandhi KN, Brown LE. 1990. Checklist of the vascular plants of Texas. College Station: Texas Agricultural Experiment Station, Texas A\&M University System.

Hermann RK. 1977. Growth and production of tree roots: A review. In: Marshall JK, ed. The Belowground Ecosystem: A Synthesis of Plant-Associated Processes. Fort Collins: Colorado State University 7-28.

Karrenberg S, Blaser S, Kollmann J, Speck T, Edwards PJ. 2003. Root anchorage of samplings and cuttings of woody pioneer species in a riparian environment. Functional Ecology 17:170-177. DOI: 10.1046/ j.1365-2435.2003.00709.x

Lim J, Zheng JQ, Masters K, Chen WW. 2010. Mechanical behavior of A265 single fibers. Journal of Material Sciences 45:652-66. DOI: 10.1007/s 10853-009-3979-5

Mattia C, Bischetti GB, Gentile F. 2005. Biotechnical characteristics of root systems of typical Mediterranean species. Plant and Soil 278:23-32. DOI:10.1007/s11104-005-7930-5

Mickovski SB, Bengough AG, Brandsby MF, Davies MCR, Hallett PD, Sonnenberg, R. 2007. Material stiffness, branching pattern and soil matric potential affect to pull out resistance of model root systems. European Journal of Soil Science 58:1471-1481. DOI: 10.1111/j.1365-2389.2007.00953.x

Morgan RPC, Rickson RJ, eds. 1995. Slope Stabilization and Erosion Control: A Bioengineering Approach. London: Taylor \& Francis.

Nixon K. 1998. Quercus rysophylla. The IUCN Red List of Threatened Species. Version 2014.2. URL:<www.iucnredlist.org> (Accessed: 04/2015)

O'Loughling C, Watson A. 1979. Root-wood strength deterioration in radiate pine after clearfelling. New Zeland Journal of Forestry Sciences 9:284-293.

Operstein V, Frydman S. 2000. The influence of vegetation on soil strength. Ground Improvement 4:81-89. DOI:10.1680/grim.2000.4.2.81

Pollen N. 2007. Temporal and spatial variability in root reinforcement of steambanks: accounting for soil shear strength and moisture. Catena 69:197-205. DOI:10.1016/j.catena.2006.05.004

Pollen N, Simon A. 2005. Estimating the mechanical effects of riparian vegetation on steam bank stability using a fiber bundle model. Water Resources Research 41:1-11. DOI: 10.1029/2004WR003801

Reubens B, Moeremans C, Poesen J, Nyssen J, Tewoldeberhan S, Franzel D, Deckers J, Orwa C, Muys B. 2011. Tree species selection for land rehabilitation in Ethiopia: from fragmented knowledge to an integrated multi-criteria decision approach. Agroforestry Sytems 82:303-330. DOI: 10.1007/s10457011-9381-8

Sanchez-Castillo L, Kubota T, Cantu-Silva I, Hasnawir. 2015. Critical Rainfall for the Triggering of Sediment Related Disasters under the Urban Forest Development in Nuevo Leon, Mexico. International Journal of Ecology \& Development 30:1-10.

Schwarz M, Cohen D, Or D. 2010. Root-soil mechanical interactions during pull-out and failure of root bundles. Journal of Geophysical Research 115:F04035. DOI:10.1029/2009JF001603

Sirichaisit J, Young RJ. 1999. Tensile and compressive deformation of polypyridobisimidazole (PIPD)based 'M5' rigid-rod polymer fibres. Polymer 40:3421-3431. DOI: 10.1016/S0032-3861(98)00561-8

Stokes A, Atger C, Bengough AG, Fourcaud T, Sidle RC. 2009. Desirable plant root traits for protecting natural and engineering slopes against landslides. Plant and Soil 324:1-30. DOI: 10.1007/s11104-0090159-y

Stokes A, Douglas, GB, Foucard T, Giadrossich F, Gillies C, Hubble T, Kim JH, Loades KW, Mao Z, McIvor IR, Michovski SB, Mitchell S, Osman N, Phillips C, Poesen J, Polster D, Preti F, Raymond P, Rey F, Schwarz M, Walker LR. 2014. Ecological mitigation of hillslope instability: ten issues facing researchers and practitioners. Plant and Soil 377:1-23. DOI: 10.1007/s11104-014-2044-6

Tosi M. 2007. Root tensile strength relationships and their slope stability implications of three shrubs species in the Northern Apennines (Italy). Geomorphology 87:268-283. DOI: 10.1016/ j.geomorph.2006.09.019

Vergani C, Chiaradia EA, Bassanelli C, Bischetti GB,. 2014. Root strength and density decay after felling in a Silver Fir-Norway Spruce stand in the Italian Alps. Plant and Soil 377:6-81.

Walker LR, Shiels AB. 2013. Landslide ecology. Cambridge: Cambridge University Press.

Watson A, Phillips C, Marden M. 1999. Root strength, growth, and rates of decay: root reinforcement changes of two species and their contribution to slope stability. Plant and Soil 217:39-47. DOI: 10.1023/ A:1004682509514

Wu TH, Watson A. 1998. In situ shear tests of soil blocks with roots. Canadian Geotechnology Journal 35: 579-590. 